Pendas : Jurnal IImiah Pendidikan Dasar, ISSN Cetak : 2477-2143 ISSN Online : 2548-6950 Volume VI Nomor 01, Juni 2021

\title{
PENGARUH MODEL CONTEXTUAL TEACHING AND LEARNING TERHADAP KEMAMPUAN PEMECAHAN MASALAH MATEMATIKA SISWA KELAS IV SDN CIKOKO 03 JAKARTA SELATAN
}

\author{
Nurkamila1, Winda Amelia ${ }^{2}$ \\ ${ }^{12}$ PGSD FKIP Universitas Trilogi \\ 1nurkamila98@gmail.com, 2nda.amien@gmail.com
}

\begin{abstract}
The purpose of this research is to see the effect of the application of the contextual teaching and learning model on the ability of fourth grade students in solving mathematical problems in fractional material. This research was conducted at SDN Cikoko 03 with fourth grade students, second semester of the 2020/2021 academic year, as samples using the Cluster Random Sampling technique. Quasi-experimental research methods (quasi-experimental research) and pretest-posttest control group design were used in this study. The question instrument in the form of a description that has been validated theoretically and empirically is used as a tool to collect data. Data analysis was carried out with normality test and homogeneity test which stated that the data was normally distributed and homogeneous. Next, the researcher tested the hypothesis with a $t$-test, the results obtained were tcount $=8.25$, for the $t$-table value because the significance level was 0.05 and $d k=62$ so that the $t$-table was 1.99. Then the acquisition of the t-count value is greater than the t-table value $(8.25>1.99)$ or in other words the null hypothesis statement can be rejected and the alternative hypothesis statement accepted. Therefore, with the acceptance of the alternative hypothesis, the application of the Contextual Teaching and Learning model in learning mathematics can be stated to have a positive impact on increasing students' mathematical problem solving abilities in grade IV SDN Cikoko 03 South Jakarta.
\end{abstract}

Keywords: contextual teaching and learning, math problem solving skills

\begin{abstract}
ABSTRAK
Tujuan dilakukannya penelitian ini yaitu untuk melihat pengaruh dari penerapan model contextual teaching and learning terhadap kemampuan siswa kelas IV dalam memecahkan masalah matematika pada materi pecahan. Penelitian ini dilaksanakan di SDN Cikoko 03 dengan siswa kelas IV, semester II tahun ajaran 2020/2021, sebagai sampel dengan penggunaan teknik Cluster Random Sampling. Metode penelitian eksperimen semu (quasi experiment research) dan desain penelitian pretest-posttest control group design digunakan dalam penelitian ini. Instrumen soal berbentuk uraian yang telah tervalidasi secara teoritis dan empiris dijadikan sebagai alat mengumpulkan data. Penganalisisan data dilakukan dengan uji normalitas dan uji homogenitas yang menyatakan bahwa data telah terdistribusi normal dan homogen. Selanjutnya, peneliti melakukan uji hipotesis dengan uji-t, yang diperoleh hasil thitung $=8,25$, untuk nilai t tabel karena taraf signifikannya 0,05 serta $\mathrm{dk}=62$ sehingga didapatkan $t_{\text {tabel }}$ yaitu 1,99 . Maka perolehan nilai t hitung lebih besar jika dibandingkan dengan nilai $t_{\text {tabel }}(8,25>1,99)$ atau dalam kata lain pernyataan hipotesis nol dapat ditolak dan diterimanya pernyataan hipotesis alternatif. Oleh karena itu, dengan diterimanya hipotesis alternatif maka penerapan model Contextual Teaching and Learning dalam pembelajaran matematika dapat dinyatakan memberikan dampak positif terhadap peningkatan kemampuan pemecahan masalah matematika siswa di kelas IV SDN Cikoko 03 Jakarta Selatan.
\end{abstract}


Kata Kunci: Model Contextual Teaching and Learning, Kemampuan Pemecahan Masalah Matematika

\section{A. Pendahuluan}

Sekolah Dasar (SD) merupakan jenjang pendidikan dasar yang harus dilalui oleh siswa dan dijadikan syarat untuk mengikuti jenjang pendidikan menengah. Sekolah Dasar sebagai jenjang pendidikan dasar yang memberikan ilmu pengetahuan dasar yang akan dikembangkan pada tingkat pendidikan selanjutnya. Oleh karena itu, kualitas pembelajaran pada Sekolah Dasar akan mempengaruhi siswa dalam menempuh jenjang pendidikan selanjutnya.

Kurikulum memuat beberapa mata pelajaran utama yang perlu dituntaskan oleh siswa, matematika menjadi salah satu mata pelajaran utama tersebut, bukan hanya dipelajari di sekolah dasar melainkan juga dipelajari hingga ke perguruan tinggi. Pentingnya mempelajari matematika sejak siswa berada di pendidikan dasar yaitu agar siswa dibekali dengan kecakapan berpikir logis, analitis, sistematis, kritis dan kreatif, serta kecakapan bekerjasama dalam sebuah kelompok. Selain itu, penerapan ilmu matematika juga sangat erat dengan masalah dikehidupan sehari-hari sehingga siswa juga dilatih untuk memiliki kemampuan pemecahan masalah matematika. Menurut pendapat Isrok'tun \& Rosmala, dari pembelajaran matematika diharapkan seseorang mampu memecahkan sebuah masalah dan memikirkan bagaimana menemukan jawaban atas pertanyaan yang ada di dalam matematika (Isrok'tun \& Amelia Rosmala, 2018).

Kemampuan

pemecahan masalah matematika yaitu kecakapan siswa dalam mengatasi sebuah persoalan matematika baik berupa soal matematika maupun yang dapat ditemukan dalam kehidupan bermasyarakat. Menurut Effendi (Fitrah, 2016) mendefinisikan pemecahan masalah yakni sebuah proses untuk mendapatkan solusi dari permasalahan yang sedang dihadapi. Selain itu, menurut pendapat Kesumawati, kemampuan memecahan masalah matematika adalah kecakapan dalam penentuan faktor-faktor yang diketahui, ditanyakan, dan kelengkapan faktor yang dibutuhkan, penyusunan model matematika dari faktor yang 
Pendas : Jurnal IImiah Pendidikan Dasar, ISSN Cetak : 2477-2143 ISSN Online : 2548-6950 Volume VI Nomor 01, Juni 2021

diketahui,

pemilihan

dan

pengembangan strategi pemecahan, serta penjelasan dan pemeriksaan hasil yang diperoleh (Mawaddah \& Anisah, 2015).

Proses penyelesaian masalah sangat dibutuhkan pengetahuan, keterampilan dan pengalaman yang dimiliki siswa. Memecahkan masalah matematika juga diperlukan keterampilan berpikir yang kompleks, yaitu kemampuan kognitif dan kesadaran kognitif dan kesadaran siswa terhadap proses kognitif tersebut (Rotul Aini, 2018). Menurut Polya (Fitrah, 2016) pemecahan masalah matematika dapat dilakukan dengan menerapkan langkah-langkah pemecahan masalah, yaitu dengan mengidentifikasi masalah yang diketahui dan diajukan dalam masalah matematika, merencanakan dan memecahkan masalah tersebut, dan menarik kesimpulan dari jawaban yang ditemukan.

Berdasarkan hasil observasi di kelas IV-B pada SDN Cikoko 03, ditemukan bahwa kecakapan siswa kelas IV-B dalam memecahankan masalah dianggap masih kurang. Keadaan ini tampak saat siswa mengerjakan latihan matematika, siswa masih kesulitan dalam menyelesaikan

permasalahan matematika yang dihadapinya. Keadaan ini disebabkan oleh proses pembelajaran mengarah kepada teacher center saat pelajaran matematika membuat siswa mengalami kebosanan, sehingga tidak fokus dalam menerima materi yang diajarkan.

Keadaan ini juga selaras dengan situasi saat virus Covid-19 masuk ke Indonesia, pada bulan Maret 2020, proses belajar mengajar di sekolah beralih menjadi Pembelajaran Jarak Jauh (PJJ) yang mana siswa belajar di rumah dengan mengikuti pembelajaran secara daring. Berdasarkan hasil observasi, pelaksanaan Pembelajaran Jarak Jauh (PJJ) yang diterapkan di SDN Cikoko 03 dinilai masih kurang optimal. Pembelajaran daring yang dilakukan guru dan siswa kelas IV di SDN Cikoko 03 hanya dilakukan di aplikasi whatsapp, dimana guru hanya memberikan arahan kepada siswa untuk mempelajari materi lewat buku ataupun video pembelajaran tanpa adanya kegiatan pembelajaran yang bersifat interaksi dua arah antara guru dan siswa secara langsung, seperti video call. Akibatnya siswa kelas IV kurang 
Pendas : Jurnal Ilmiah Pendidikan Dasar, ISSN Cetak : 2477-2143 ISSN Online : 2548-6950 Volume VI Nomor 01, Juni 2021

memahami materi pelajaran dan kemampuan pemecahan masalah tidak dapat terasah dengan baik, serta pembelajaran tidak lagi memperhatikan karakteristik siswa.

Perbedaan karakteristik siswa di dalam kelas sangat beragam, baik dari usia siswa maupun cara belajar siswa. Namun secara umum, siswa sekolah dasar senang belajar dengan benda-benda yang konkret atau belajar dengan mengaitkan permasalahan nyata pada aktivitas kesehariannya. Semakin tinggi tingkatan kelasnya akan semakin tinggi pula tingkat kesulitan soal pemecahan masalah yang dihadapinya. Memecahkan masalah bukan hanya sekedar kemampuan dalam menyelesaikan soal matematika, tetapi juga kemampuan dalam memahami materi saat belajar. Melalui pemecahan masalah pula, bukan hanya perkembangan kognitif yang akan didapatkan oleh siswa, melainkan juga perkembangan mental dan emosi siswa, sehingga siswa terlatih dalam menyelesaikan permasalahan kehidupan.

Untuk itulah, guru perlu menyelenggarakan pembelajaran yang menyenangkan dan menyesuaikan karakteristik siswa yang ada di kelasnya, agar siswa merasa nyaman saat belajar matematika. Salah satu model pembelajaran yang dapat digunakan guru dalam pembelajaran matematika adalah model Contextual Teaching and Learning (CTL). Model Contextual Teaching and Learning yaitu model pembelajaran yang mengikutsertakan siswa untuk turut aktif saat proses pembelajaran serta mengaitkan pengetahuan dengan aktivitas kesehariannya sehingga penerapan pengetahuan baru dalam aktivitas sehari-hari dapat dilakukan oleh siswa.

Pendapat yang selaras juga dikemukakan oleh Ngalimun yakni Pembelajaran Kontekstual merupakan proses belajar mengajar yang diawali melalui kegiatan tanya jawab dan mengaitkan materi ke dunia nyata siswa, sehingga diharapkan suasana menyenangkan dan kebermaknaan dalam belajar dapat tercipta didalam kelas (Ngalimun, 2017). Menurut Setyawati,dkk penerapan model pembelajaran kontekstual yang mengutamakan siswa untuk menerapkan pengetahuan dalam kehidupan sehari-hari dapat mempermudah siswa memahami 
Pendas : Jurnal Ilmiah Pendidikan Dasar, ISSN Cetak : 2477-2143 ISSN Online : 2548-6950 Volume VI Nomor 01, Juni 2021

ilmu pengetahuan yang dipelajarinya (Hesti Lilis Setyawati et al., 2020). Pengajaran dengan model Contextual Teaching and Learning, menuntut siswa untuk memiliki pemikiran yang kritis serta belajar lebih aktif dalam memahami materi yang dikaitkan dengan aktivitas keseharian yang di lingkungannya. Selain itu juga, penekanan pada bagaimana siswa dapat mengaplikasikan pengetahuan yang dimilikinya dengan memecahkan persoalan dalam aktivitas kesehariannya.

Berdasarkan penjelasan di atas, peneliti terdorong untuk menggarap penelitian yang menerapkan model Contextual Teaching and Learning untuk melihat pengaruhnya terhadap kemampuan pemecahan masalah matematika siswa kelas IV di SDN Cikoko 03. Demikian, peneliti menentukan judul untuk penelitian ini yaitu "Pengaruh Model Contextual Teaching and Learning terhadap Kemampuan Pemecahan Masalah Matematika Siswa Kelas IV di SDN Cikoko 03 Jakarta Selatan".

\section{B. Metode Penelitian}

Metode penelitian semu atau quasi experimental research, metode penelitian yang dipiih, karena penelitian ini ditujukan untuk melihat pengaruh tindakan yang diaplikasikan oleh peneliti, yaitu model contextual teaching and learning, terhadap variabel lain, yaitu kemampuan siswa kelas IV di SDN Cikoko 03 Jakarta Selatan dalam memecahkan masalah matematika. Metode penelitian eksperimen semu merupakan penelitian eksperimen yang tidak sekuat eksperimen murni, karena pada penelitian ini terdapat variabel yang tidak dapat dikontrol, sehingga sulit untuk dilakukan eksperimen sebenarnya (eksperimen murni) (Payadnya \& Jayantika, 2018).

Desain penelitian yang digunakan yaitu desain "PretestPosttest Control Grup Design". Desain penelitian ini diilustrasikan pada tabel berikut.

Tabel 1 Desain Penelitian PretestPosttest Control Group Desaign

\begin{tabular}{ccccc}
\hline Grup & $\begin{array}{c}\text { Prete } \\
\text { st }\end{array}$ & $\begin{array}{c}\text { Perla } \\
\text {-kuan }\end{array}$ & $\begin{array}{c}\text { Pos } \\
\text { t- } \\
\text { test }\end{array}$ \\
\hline $\mathrm{R}$ & Eksperimen & $0_{1}$ & $\mathrm{X}$ & $0_{2}$ \\
\hline $\mathrm{R}$ & Kontrol & $0_{3}$ & $\mathrm{C}$ & $0_{4}$ \\
\hline
\end{tabular}

Sumber: (Kurniawan, 2018)

Keterangan:

$\mathrm{R}=$ Grup eksperimen atau kontol yang dipilih secara random

$X=$ Grup eksperimen yang diberi perlakuan dengan model contextual teaching and learning 
Pendas : Jurnal Ilmiah Pendidikan Dasar, ISSN Cetak : 2477-2143 ISSN Online : 2548-6950 Volume VI Nomor 01, Juni 2021

$\mathrm{C}=$ Grup kontrol yang diberi perlakuan dengan model pembelajaran konvensional

$01=$ Perolehan hasil pretest grup eksperimen

$\mathrm{O}_{2}=$ Perolehan hasil posttest grup eksperimen

$0_{3}=$ Perolehan hasil pretest grup kontrol

$\mathrm{O}_{4}=$ Perolehan hasil posttest grup kontrol

Penelitian diselenggarakan di

SDN Cikoko 03 Jakarta Selatan.

Populasi dalam penelitian ini adalah seluruh siswa kelas IV SD Negeri di Kelurahan Cikoko Jakarta Selatan. Sampel yakni seluruh siswa kelas IV SDN Cikoko yang berjumlah 64 siswa yang dipilih melalui penggunaan teknik cluster sampling.

Pengumpulan data dilakukan melalui pretest dan posttest pada grup eksperimen dan grup kontrol. Kegiatan pretest dan posttest ini bertujuan untuk mendapatkan data hasil kemampuan siswa kelas IV SDN Cikoko 03 dalam memecahkan persoalan matematika dengan penerapan model contextual teaching and learning (CTL) pada materi pecahan. Data yang diperoleh, dianalisis dengan uji hipotesis yakni menggunakan rumus uji-t.

Instrumen pengumpulan data yang digunakan oleh peneliti yaitu lembar tes uraian yang berjumlah 13 butir. Instrumen tersebut telah di uji secara teoritis melalui expertjudgment dengan dosen dan tenaga penddik serta uji secara empiris melalui uji coba lapangan di SDN Cikoko 01 Jakarta Selatan yang teruji validitas dan reliabilitasnya, sehingga setiap butir soal dalam instrumen dapat dinyatakan layak untuk digunakan sebagai alat pengumpul data penelitian.

Data penelitian diperoleh melalui hasil tes yang diberikan kepada grup eksperimen dan kontrol pada awal pembelajaran (pretest) untuk melihat kemampuan awal siswa dalam memesahkan masalah matematika sebelum diberikan perlakuan. Kemudian, siswa juga diberi lembar tes di akhir pembelajaran (posttest) untuk melihat kemampuan siswa dalam memecahkan masalah matematika setelah diberikan perlakuan yang berbeda. Selanjutnya data dianalisis dengan pengujian hipotesis menggunaan rumus uji-t. Adapun persyaratan yang harus dilalui sebelum uji hipotesis dilakukan, yaitu dengan menganalisis data melalui uji normalitas dan uji homogenitas, untuk membuktikan bahwa data yang 
Pendas : Jurnal Ilmiah Pendidikan Dasar, ISSN Cetak : 2477-2143 ISSN Online : 2548-6950 Volume VI Nomor 01, Juni 2021

diperoleh telah terdistribusi normal dan bersifat homogen.

\section{Hasil Penelitian dan Pembahasan}

Data yang diperoleh pada penelitian ini, yaitu hasil pretest dan posttest kemampuan siswa dari grup eksperimen dan grup kontrol dalam memecahkan masalah matematika pada materi pecahan di kelas IV. Berikut disajikan tabel data hasil pretest kemamapuan pemecahan masalah matematika siswa kelas IV dari kedua grup.

Tabel 2 Data Hasil Pretest Penelitian

\begin{tabular}{lllll}
\hline Data/Sumber & $\mathbf{N}$ & $\begin{array}{c}\text { Skor } \\
\text { Max }\end{array}$ & $\begin{array}{c}\text { Skor } \\
\text { Min }\end{array}$ & $\begin{array}{c}\text { Mean } \\
(\overline{\mathbf{X}})\end{array}$ \\
\hline Eksperimen & 32 & 98 & 13 & 44,25 \\
\hline Kontrol & 32 & 110 & 13 & 54,2 \\
\hline
\end{tabular}

Berdasarkan perolehan pre-test di atas, dapat dijabarkan bahwa pada grup eksperimen yang terdiri dari 32 siswa terdapat nilai terendah yaitu 13 dan nilai tertinggi yaitu 98 . Selain itu, perhitungan statistik deskriptif menunjukan perolehan rata-rata grup eksperimen yaitu 44,25. Sementara grup kontrol yang juga terdiri dari 32 siswa terdapat nilai terendah yaitu 13 dan nilai tertinggi yaitu 110. Selain itu, perhitungan statistik deskriptif menunjukan perolehan rata-rata grup kontrol yaitu 54,2 .

Adapun data posttest yang diperoleh peneliti setelah memberikan perlakuan yang berbeda pada kedua grup, yakni grup eksperimen dengan model contextual teaching and learning sedangkan grup kontrol dengan model pembelajaran konvensional. Berikut disajikan tabel data hasil posttest kemampuan pemecahan masalah matematiak siswa kelas IV dari kedua grup.

\section{Tabel 3 Data Hasil Posttest} Penelitian

\begin{tabular}{llllc}
\hline Data/Sumber & $\mathbf{N}$ & $\begin{array}{l}\text { Skor } \\
\text { Max }\end{array}$ & $\begin{array}{c}\text { Skor } \\
\text { Min }\end{array}$ & $\begin{array}{c}\text { Mean } \\
(\overline{\mathbf{X}})\end{array}$ \\
\hline Eksperimen & 32 & 147 & 53 & 102,4 \\
\hline Kontrol & 32 & 121 & 16 & 69,1 \\
\hline
\end{tabular}

Berdasarkan perolehan posttest di atas, dapat dijabarkan bahwa pada grup eksperimen terdapat skor minimal yaitu 53 dan skor maksimal yaitu 147. Selain itu, perhitungan statistik deskriptif menunjukan perolehan rata-rata grup eksperimen yaitu 102,4. Sementara grup kontrol terdapat nilai terendah yaitu 16 dan nilai tertinggi yaitu 121 . Selain itu, perhitungan statistik deskriptif menunjukan perolehan rata-rata grup kontrol yaitu 69,1 . 
Pendas : Jurnal Ilmiah Pendidikan Dasar, ISSN Cetak : 2477-2143 ISSN Online : 2548-6950 Volume VI Nomor 01, Juni 2021

Uji Hipotesis

Penganalisisan data untuk pengujian hipotesis dilakukan melalui penggunaan rumus uji-t dengan taraf signifikan (a) yakni 0,05 serta perhitungan akan menggunakan Microsoft Office Excel 2010. Uji-t digunakan untuk melakukan perbandingan selisih skor pada saat mengadakan pretest dan posttest untuk grup eksperimen dan grup kontrol. Pernyataan $\mathrm{H}_{0}$ dapat ditolak dan diterimanya pertanyaan $\mathrm{H}_{1}$, apabila nilai thitung yang diperoleh lebih besar dibandingkan ttabel. Rumusan hipotesis statistik yang digunakan.

1) $\mathrm{H}_{0}=\bar{X}_{1} \leq \bar{X}_{2}$, artinya kemampuan pemecahan masalah matematika siswa yang pengajarannya menggunakan model contextual teaching and learning lebih buruk atau sama dengan siswa yang pengajarannya menggunakan pembelajaran konvensional.

2) $\mathrm{H}_{1}=\bar{X}_{1}>\bar{X}_{2}$, artinya kemampuan pemecahan masalah matematika siswa yang pengajarannya menggunakan model contextual teaching and learning lebih baik dari siswa yang pengajarannya menggunakan

pembelajaran konvensional yang merupakan hipotesis.
Berdasarkan perolehan uji normalitas dan homogenitas dapat diakui bahwa data dari kedua grup tersebut terdistribusi normal dan homogen, maka selanjutnya, peneliti melakukan uji hipotesis melalui uji-t. Berikut disajikan tabel hasil perhitungan uji-t.

Tabel 4 Uji Hipotesis

\begin{tabular}{ccccc}
\hline $\mathbf{d k}$ & $\propto$ & $\mathbf{t}_{\text {hitung }}$ & $\mathbf{t}_{\text {tabel }}$ & Kesimpulan \\
\hline 62 & 0,05 & 8,25 & 1,99 & $\begin{array}{c}\mathrm{H}_{0} \text { ditolak } \\
\mathrm{H}_{1} \text { diterima }\end{array}$ \\
\hline
\end{tabular}

Perolehan uji-t dalam penelitian ini, yakni thitung $=8,25$, untuk nilai $t$ tabel karena taraf signifikannya 0,05 serta $\mathrm{dk}=62$ sehingga didapatkan $\mathrm{t}$ tabel yaitu 1,99. Maka perolehan nilai $\mathrm{t}$ hitung lebih besar dari nilai $\mathrm{t}$ tabelnya $(8,25>1,99)$ atau dalam kata lain pernyataan hipotesis nol dapat ditolak dan diterimanya pernyataan hipotesis alternatif. Oleh karena itu, dengan diterimanya hipotesis alternatif maka terbukti bahwa dampak positif dengan diterapkannya model contextual teaching and learning dapat membawa peningkatan terhadap kemampuan siswa kelas IV SDN Cikoko 03 dalam memecahkan masalah matematika.

Pengaruh penerapan model Contextual Teaching and Learning 
Pendas : Jurnal Ilmiah Pendidikan Dasar, ISSN Cetak : 2477-2143 ISSN Online : 2548-6950 Volume VI Nomor 01, Juni 2021

pada grup eksperimen, terlihat saat proses pembelajaran yang dilaksanakan menggunakan via aplikasi Zoom. Penggunaan media, gambar-gambar, dan ilustrasi permasalahan yang berkaitan dengan kehidupan nyata membuat proses pembelajaran disukai oleh siswa. Selain itu, kegiatan diskusi dan tanya jawab berkaitan dengan latihan soal yang dilengkapi dengan gambar membuat suasana belajar lebih interaktif. Hal tersebut mengakibatkan pemahaman siswa terhadap materi lebih meningkat sehingga siswa dapat digunakan / mengaplikasikan pemahamannya dalam menjawab pertanyaan dalam soal matematika.

Sementara penerapan model pembelajaran konvensional yang dilaksanakan di grup kontrol melalui aplikasi zoom, kegiatan belajar mengajarnya lebih mengarah kepada teacher center, sehingga saat belajar peneliti hanya memberikan penjelasan secara verbal kepada siswa. Hal ini mengakibatkan siswa tidak aktif mencari informasi secara mandiri serta membuat kemampuan berpikir dan kemampuan siswa dalam memecahkan masalah matematika kurang berkembang maksimal. Kemampuan siswa grup eksperimen dan kontrol dalam memecahkan masalah matematika, terlihat pada peningkatan selisih dari nilai rerata arat rata-rata hasil pretest dan posttest. Perolehan rerata hasil pretest grup eksperimen yaitu 44,25 dan posttest 102,4, sedangkan perolehan rata-rata hasil pretest grup kontrol yaitu 54,2 dan posttest 69,1. Perolehan rata-rata grup eksperimen yang diterapkan model contextual teaching and learning menunjukkan peningkatan sebesar 58,15 poin lebih tinggi jika dibandingkan dengan perolehan rata-rata grup kontrol dengan peningkatan sebesar 14,9 poin, sehingga kemampuan siswa grup eksperimen dalam memecahkan masalah matematika lebih mengalami peningkatan yang signifikan dibanding grup kontrol.

\section{Berdasarkan}

perhitungan secara statistik terhadap data penelitian yang diperoleh melalui uji-t, perolehan $t$ hitung yaitu 8,25. Sementara,nilai $\mathrm{t}$ tabel dengan $\mathrm{dk}$ (jumlah sampel dikurangi dua) yaitu 62 dan taraf signifikan $(\propto) \quad 0,05$ didapatkan angka 1,99 lebih kecil dari nilai $\mathrm{t}$ hitung atau dengan kata lain hasil $t$ hitung lebih besar dibandingkan $t$ tabel, sehingga membuat diterimanya hipotesis 
Pendas : Jurnal IImiah Pendidikan Dasar, ISSN Cetak : 2477-2143 ISSN Online : 2548-6950 Volume VI Nomor 01, Juni 2021

alternative. Pernyataan hipotesis alternatif yang diterima menyatakan bahwa penerapan model contextual teaching and learning membawa pengaruh yang positif terhadap peningkatan kemampuan pemecahan masalah matematika siswa kelas IV SDN Cikoko 03 Jakarta Selatan dalam materi pecahan. Perbedaan nilai rata-rata dari hasil posttest kedua grup juga dapat membuktikan bahwa model contextual teaching and learning lebih membawa pengaruh positif serta kemampuan pemecahan masalah matematika siswa pada grup eksperimen menjadi lebih baik dibanding dengan grup kontrol, karena rata-rata grup eksperimen lebih besar yaitu 102,4 sedangkan rata-rata grup kontrol yaitu 69,1.

Berkembangnya kemampuan pemecahan masalah matematika siswa dapat disebabkan oleh proses pembelajaran yang mendukung siswa untuk dapat mengembangkan kemampuan berpikirnya. Penekanan pada kegiatan yang menuntut siswa melakukan pengaitan materi dengan persoalan nyata dalam aktivitas kesehariannya melalui proses diskusi dan interaksi antara guru dan siswa dapat mengembangkan kemampuan pemecahan masalah matematika siswa menjadi lebih baik. Penggunaan media bergambar dan media interaktif lainnya saat belajar daring melalui aplikasi zoom juga diperlukan dalam pembelajaran contectual teaching and learning untuk memicu perhatian dan motivasi belajar siswa saat berlangsungnya kegiatan belajar mengajar.

\section{Kesimpulan}

Peningkatan kemampuan pemecahan matematika siswa kelas IV di SDN Cikoko 03, pada grup eksperimen terjadi secara signifikan dibandingkan grup kontrol. Perolehan rata-rata hasil pretest grup eksperimen yaitu 44,25 dan posttest 102,4 , sedangkan perolehan rata-rata hasil pretest grup kontrol yaitu 54,2 dan posttest 69,1 . Peningkatan nilai rata-rata sebesar 58,15 poin dialami grup eksperimen yang diterapkan model contextual teaching and learning, lebih tinggi jika dibandingkan dengan peningkatan nilai rata-rata grup kontrol yang hanya sebesar 14,9 poin, sehingga kemampuan siswa grup eksperimen dalam memecahkan masalah matematika lebih mengalami peningkatan yang signifikan dibanding grup kontrol. 
Penerapan model contextual teaching and learning memberi dampak positif terhadap kemampuan pemecahan masalah matematika siswa di kelas IV SDN Cikoko 03. Kesimpulan ini didapat dari perhitungan secara statistik terhadap data penelitian yang diperoleh melalui uji-t, perolehan $\mathrm{t}$ hitung yaitu 8,25. Sementara,nilai $t$ tabel dengan $d k$ (jumlah sampel dikurangi dua) yaitu 62 dan taraf signifikan $(\propto) \quad 0,05$ didapatkan angka 1,99 lebih kecil dari nilai $t$ hitung atau dengan kata lain hasil $t$ hitung lebih besar dibandingkan $t$ tabel, sehingga membuat diterimanya hipotesis alternative. Hipotesis alternatif yang diterima, menyatakan bahwa dengan diterapkannya model contextual teaching and learning membawa dampak positif terhadap peningkatan kemampuan siswa kelas IV SDN Cikoko 03 dalam memecahankan masalah matematika.

\section{DAFTAR PUSTAKA}

Fitrah, M. (2016). Model Pembelajaran Matematika Sekolah: Kajian Perspektif Berdasarkan Teori dan Hasil Riset. Deepublish.

Hesti Lilis Setyawati, D., Fakhriyah,
F., \& Khamdun, K. (2020). Peningkatan Berpikir Kritis Siswa Sekolah Dasar Dengan Menerapkan Model Contextual Teaching and Learning Berbantuan Media Lempar Karet Pengetahuan. Pendas: Jurnal Ilmiah Pendidikan Dasar, 5(Vol 5 Nomor 2 Desember 2020), 130 139.

https://doi.org/10.23969/jp.v5i2.3 426

Isrok'tun, \& Amelia Rosmala. (2018). Model-Model Pembelajaran Matematika. Bumi Aksara.

Kurniawan, A. (2018). Metodologi Penelitian Pendidikan. PT. Remaja Rosdakarya.

Mawaddah, S., \& Anisah, H. (2015). Kemampuan Pemecahan Masalah Matematis Siswa Pada Pembelajaran Matematika dengan Menggunakan) di SMPN Model Pembelajaran Generatif (Generative Learning) di SMP. EDU-MAT: Jurnal Pendidikan Matematika, 3(2), 166-175. https://doi.org/10.20527/edumat. v3i2.644

Ngalimun. (2017). Strategi Pendidikan. Penerbit Parama IImu.

Payadnya, I. P. A., \& Jayantika, I. G. A. (2018). Panduan Penelitian Eksperimen Beserta Analisis Statistik dengan SPSS - I Putu Ade Andre Payadnya dan I Gusti Agung Ngurah Trisna Jayantika Google Buku. Retrieved June 23, 2021, from 
https://books.google.co.id/books ?id=NaCHDwAAQBAJ\&printsec $=$ frontcover\&dq=panduan+peneliti an+eksperimen\&hl=id\&sa=X\&ve $\mathrm{d}=0$ ahUKEwichd_5gqzpAhV06n MBHYZCA0QQ6AEIKDAA\#V=on epage\&q=panduan penelitian eksperimen\& $f=f a l s e$

Rotul Aini, Q. (2019). Profil Metakognisi Siswa Sekolah Dasar Dalam Menyelesaikan Masalah Matematika Ditinjau Dari Gaya Kognitif. Pendas: Jurnal IImiah Pendidikan Dasar, 2(2), 2477-2143.

https://doi.org/10.23969/jp.v3i2.1 129 